Article

\title{
Religious Education in Russia: Inter-Faith Harmony or Neo-Imperial Toleration?
}

\author{
Elena Lisovskaya \\ Department of Sociology, Western Michigan University, Kalamazoo, MI 49008-5257, USA; \\ E-Mail: elena.lisovskaya@wmich.edu
}

Submitted: 14 November 2015 | Accepted: 18 February 2016 | Published: 19 April 2016

\begin{abstract}
This paper explores the approach to religious education that has been instituted in Russia since 2012. The new policy's manifestly proclaimed goals seem convergent with the values of religious freedom, self-determination, tolerance, and inter-faith peace that are espoused by Western liberal democracies. Yet Russia's hidden religious education curriculum is far more consistent with a neo-imperial model of ethno-religious (Russian Orthodox) hegemony and limited toleration of selected, other faiths whose reach is restricted to politically peripheral ethno-territorial entities. This model embodies and revitalizes Russia's imperial legacies. Yet the revitalization is, in itself, an outcome of strategic choices made by the country's religious and secular elites in the course of its desecularization. Building on discourse analysis of five Russian textbooks and a teacher's manual, this article shows how the neo-imperial model manifests itself in the suppression of exogenous and endogenous pluralism, cultivation of the ideology of "ethnodoxy", and in essentially imperialist mythology. The paper concludes by predicting the new model's potential instability.
\end{abstract}

\section{Keywords}

education; ethnicity; multiculturalism; religion; Russia; hidden curriculum, neo-imperialism

\section{Issue}

This article is part of the issue "Religious Diversity and Social Inclusion", edited by Gary Bouma (Monash University, Australia).

(C) 2016 by the author; licensee Cogitatio (Lisbon, Portugal). This article is licensed under a Creative Commons Attribution 4.0 International License (CC BY).

\section{Introduction: How Things May Not Be Quite What They Seem}

The drama surrounding attempts to find a place for religion in Russia's state-run schools unfolded after the collapse of the Soviet Union and its official atheism. The drama lasted more than two decades, and involved tense debates, competing initiatives, and political struggles. Yet, at least for now, the drama seems to be over. In 2012, a new policy was finally put in place. Since then, Russian state-run schools have taught the "fundamentals of religious cultures." The course received approbation in selected regions, where nearly 240,000 fourth graders took it, after then-president Dmitry Medvedev authorized the experiment in 2009. The course teaches four religious cultures. Only Orthodoxy, Islam, Buddhism, and Judaism-often dubbed
Russia's 'traditional' religions-are included. All other faiths are not. Students can study one of these four religious cultures, choose a survey of world religions, or take a secular ethics course. Russia's rulers, including Vladimir Putin, have supported the new curriculum, and there has been a push to expand it. Patriarch Kirill, the primate of the Russian Orthodox Church of Moscow Patriarchate (ROC MP), recently spoke in favor of making the course mandatory for grades two through nine or ten.

Existing literature has focused largely on the history and politics of the struggles surrounding the introduction of religion into public schooling, and-to a lesser extent-on the content of the new course and its textbooks, primarily the textbooks on Orthodox culture. This literature includes critical commentary on aspects of the new curriculum and its implementation (such as 
state patriotism and the privileging of Orthodoxy). Yet experts have also emphasized its positive, constructive aspects. These are said to include consensus building; an open-minded search for reasonable compromise between the state, religious groups, and educators; and-particularly when contrasted with Russia's pastthe curriculum's multicultural, inclusive nature.

Such evaluations evoke some of the core values that have shaped contemporary approaches to religious education in Western liberal democracies. As will be briefly discussed below, while specific policies have varied historically and cross-nationally, contemporary liberal approaches to religious education emphasize multicultural inclusion of diverse religious and secular orientations and constituencies into a shared educational and public spheres. Therefore, Russia's educational innovations may appear to bring the country closer to the aforesaid Western values. I will show that Russia's religious leaders-including, paradoxically, her staunchest proponents of the country's civilizational uniqueness-wish to present the new policy in this light. Russia, proponents say, is simply doing what the West-and especially Europe-has done all along.

This article-in contrast-shows that Russia's new policies may not be quite what they seem. On the surface, they display a multicultural compromise that resembles a liberal-democratic model of inclusion, butunder the surface-are supported by a neo-imperial regime of ethno-religious toleration that is being consolidated through the policies. Social scientists have long suggested that modern liberal-democratic forms of inclusion have been historically preceded by other ways of handling pluralism, such as through imperial regimes of toleration, which handled ethno-religious pluralism in the Russian Empire. I suggest that a modified version of an imperial regime of toleration has reemerged in post-Soviet Russia. This model secures a hegemonic role to the Orthodox Church and identifies the Russian people as "first among equals" within the neo-imperial project that has increasingly impacted the ideology, politics, and foreign policy of Russia in recent decades. These neo-imperial orientations, I argue, manifest themselves in the policy arrangements and content of the new course on religious cultures. Meanwhile, the idea of multi-cultural inclusion of diverse religious groups is used to legitimize the new policies by making them presentable and acceptable to Western critics.

I approach this task as a social scientist. My goal is not to criticize or praise Russian policies, but to show how these policies are shaped by the Russian and Soviet imperial legacies, and how the choices and strategies of Russia's religious and secular elites have contributed to a neo-imperial model of ethno-religious toleration. In particular, I link the emergence of this model to elites' decision to use a top-down approach to reviving religion (i.e., desecularizing) in Russia's insti- tutions. This paper incorporates conceptualizations of empire, imperial toleration, and desecularization with qualitative discourse analysis of five Russian textbooks and a Manual for teachers. The analysis shows how the neo-imperial model manifests itself in the texts' content.

This article begins by briefly outlining the core ideas around which a consensus on religious education seems to have emerged in liberal democracies. I then provide an overview of how Russia has approached religious education, how religious education policies have been presented by Russian leaders, and how experts have identified these policies with modern Western practices. This section is followed by an analysis of the imperial and neo-imperial political and ideological context of Russia's policies. I build on desecularization theory and research to suggest that Russia's religious and secular leaders have opted for a desecularization "from above", which has led to the re-emergence of a neo-imperial pattern of religious hegemony and limited toleration of ethno-religious pluralism. Finally, I show how these neo-imperial orientations have manifested in the ideological context of the new textbooks.

\section{Liberal Democratic Consensus in Religious Education}

In order to understand how the emerging Russian model of religious education differs from the model in Western liberal democracies, let us look at the nature of the model around which Western democracies have built consensus. There is no doubt that existing approaches to and forms of religious education in Western liberal democracies vary historically, crossnationally, and intra-nationally. These variations reflect the different patterns of historical church-state and church-state-and-school relations in democratic societies (Monsma \& Soper, 1997); prevalent models for regulating religion in the public sphere, including in education (Richardson, 2004; Plesner, 2005a); and country-specific historical trajectories and institutional arrangements for integrating religious minorities (Fetzer \& Soper, 2005). In the US, the First Amendment to the Constitution and the country's strict separation of church and state placed religious education beyond the scope of public education. In most of Europe, religious education has been incorporated in public school curricula. Generally speaking, models of religious education in Europe include:

(a) teaching religion as a separate and official school subject, a subject for which the state may have sole responsibility (as in the UK and Norway) or co-responsibility with the churches (as in most German states);

(b) offering religion outside formal curricula, and under the control of the church or other faith communities (as in the German 
states of Brandenburg and Berlin); and

(c) teaching religious traditions within history, social studies, or other subjects (e.g., in France with exception of Alsace-Lorraine) (Plesner, 2005b, p. 1).

Approaches to religious education in public schools vary in many other ways, such as in whether one teaches in, for, or about religion; whether one presents the subject as a devotion or confessional; whether one teaches students in segregated or integrated classrooms; and whether one offers religious education as an elective or mandatory course (e.g., Jackson et al., 2007; Lahnemann \& Schreiner, 2009). Similarly complex and diversified is the landscape of forms and approaches to religious education in liberal democracies outside of Europe. Thus in most Australian states, religious instruction remains an important feature of public school curricula, while the schools of Canadian Ontario teach religion in a neutral way, and Quebec just introduced religious education as a subject for primary and secondary schools in 2008 (for a survey of nonEuropean approaches to religious education, see-for example-Beaman \& Van Arragon, 2015). Yet amidst the growing religious and cultural diversity of the Western world, the need to develop a set of international principles and standards (compatible with basic democratic principles) for incorporating religion into public education became pressing, and commonly recognized among the West's educational administrations and scholarly communities. Europe took a leading role in developing these principles. Despite the considerable plurality of conceptualizations, institutionalizations, and practices of religious education in European democracies,

"there have been several significant European-wide developments that aim toward the creation of a more general, trans-national consensus regarding the rationale and guidelines for RE [religious education-E.L.] in public schools. These developments include public statements and research activities sponsored by the European Union, projects and documents developed by the Council of Europe, and initiatives undertaken by the Organization for Security and Cooperation in Europe (OSCE)." (Grelle, 2015, pp. 236-237)

A consensus regarding religious education has been reached during these activities, and endorsed in the Toledo Guiding Principles of Teaching about Religions and Beliefs in Public Schools (OSCE, 2007). The consensus serves as "a basis for the study of religions in educational institutions across Europe and beyond that is not driven by any theological agenda, but rather relates to human rights, citizenship and intercultural education arguments" (Jackson, 2010, p. vii). This consen- sus is not about a particular form of religious education, but about the general principles and framework within which particular jurisdictions should design their specific forms of religious incorporation in curricula. This framework is grounded in the democratic values of human rights and religious freedom. It establishes international standards that prohibit violations of these rights, and prevent indoctrination of students into any particular system of religious values or dogmas. Van Arragon and Beaman suggest modern democracies agree that a country's chosen model should cause no harm to religious or non-religious minorities "by practices they experience as coercive indoctrination" (2015, pp. 3-4). They emphasize that, particularly in public schools, "the quest is for a mechanism which will both protect the religious freedoms of religious groups while at the same time persuading students to see their religions and religious traditions in the context of wider, commonly accepted civic values and interests" (p. 3).

These guiding principles give public schools the charge to accommodate religious constituencies with respect to their rights and freedoms, and-by doing sohelp build inter-religious and "intercultural understanding, tolerance and harmony (Weisse, 2007, p. 17). The sociologist Jean-Paul Willaime (2007) notes that, "whatever their legal framework, all European countries are facing the question of how to approach religious faith respecting the freedom of conscience of students and their families while at the same time educating them towards freedom of thought and a critical stance" (p. 100). As such, religious education (as education about and from religions) is perceived by leading European scholars as another form of civic education, which facilitates the development of European and global values of citizenship and cultural pluralism (Jackson, 2003, 2007). Thus it seems that-amidst the diversity of national, socio-historical, and legal contexts, and in the varied forms of religion's delivery into schools - there is indeed a consensus on principles and desirable outcomes.

This developing consensus is a commonly shared approach, and is rooted in the cornerstone principles of liberal democracy. It views the harmonious unity of diverse groups as a result of policies and structural arrangements that are based on respect for religious freedom, choice, and cultural self-determination. Findings from the EU-funded research project, Religion in Education. A Contribution to Dialogue or a Factor of Conflict in Transforming societies of European Countries, 2006-2009 (REDCo), suggest that this approach succeeds, and brings desirable outcomes. Thus it was found that students from countries with different, even polar, models of religious education (e.g., English versus French) reported that at school they "learn to respect everyone, whatever their religion" (Jozsa, 2010, p. 43). The liberal democratic approach respects freedom of critical thought, which precludes hegemonic imposition of religious views and ascription of religious 
identities. And it is in this regard, we will see, that the liberal democratic approach differs from the emerging Russian model. However, in order to see how and why the Russian model is different, let us look at how the model developed and at its essential traits.

\section{Teaching Religious Cultures: A Brief History and Basic Facts}

By all historical accounts, attempts to find a place for religion in public schooling date back to the fall of the Soviet rule and the emergence of post-Soviet Russia; that is, they date back to the end of the 1980s and the early 1990s. Some highly positioned members of the political, administrative, intellectual, and religious elites lobbied for and contributed to the process of introducing religions into schools. The process lasted more than two decades, and has gone through a number of dramatic stages. It was marked by considerable struggles between the forces that promoted and supported a (re)introduction of religious education and those who opposed it (see Lisovskaya \& Karpov, 2005, 2010, for an analysis of the social and political dynamics of the struggle). The ROC MP, Russia's largest and most influential religious organization, played a key role in the process. Initially, the ROC MP insisted on teaching only one course, on Orthodox Culture. In 2002, Minister of Education Filippov signed an order introducing the course on Orthodox Culture into the basic curricula of municipal schools. A highly controversial textbook, Fundamentals of Orthodox Culturewritten by Alla Borodina-became the first educational text taught in the course. One year later, in 2003, after receiving heavy criticism for privileging Orthodoxy in a religiously diverse society, Filippov suggested developing a course on multiple religions instead. Orthodox hierarchs strongly objected to the suggestion; in their pursuit to preserve a separate course on Orthodoxy, they began lobbying for a confessional model of religious education, which would allow students to be taught their religious preference in separate classrooms (Vasilenko, 2005). These hierarchs might have calculated that, in a country where a vast majority of citizens (up to $80 \%$, according to some polls) identified themselves as Orthodox, a similarly vast majority of parents and students would opt for a course on Orthodox Culture; the expectation did not, however, quite materialize. In 2007-through amendments to education law-local and regional curricular components were abolished, leaving public schools bound only by the federally mandated curricular standard. The same year, the ROC MP leadership-in collaboration with the Ministry of Education-expanded the federal standard by establishing a new curricular area called SpiritualMoral Development of Russia's Citizens; the course on religious cultures became the first taught within this new division.
The process culminated in the development and implementation of a course called the Fundamentals of Religious Cultures and Secular Ethics (FRCSE), which was introduced as a mandatory component under the Federal Educational Standard through the directives of President Medvedev (August 2, 2009) and the Government of the Russian Federation (October 29, 2009). The course was taught on a trial basis in nineteen regions of the country in 2009-2010, and introduced in two more regions (the Mari Republic and Yaroslavl region) in 2011. Some observers noted that the course had been taught de facto in selected regions of the country long before it became mandatory (Glanzer \& Petrenko, 2007). In February 2012, then Prime Minister Vladimir Putin praised the experiment, and approved its expansion at a meeting with the religious leaders of Russia's major confessions while at the Danilov Monastery in Moscow (Stenogramma, 2012). After his approbation, the course was launched in all state-run general education schools. Since 2012, teachers have been required to teach the course to all fourth graders for one hour per week (34 hours total). The ROC MP leadership is currently pushing to expand the course, making it a requirement for almost the whole of elementary and secondary school (grades two through nine or ten).

How does the newly instituted approach work? Students and/or their parents are allowed to choose between six modules, five of which have an explicitly religious focus, and one of which is dedicated to secular ethics. There is one textbook for each module, and one instructional Manual for teachers (Tishkov \& Shaposhnikova, 2011). The texts focusing on religions include: Fundamentals of Orthodox Culture (FOC) (Kuraev, 2012), Fundamentals of Islamic Culture (FIC) (Latyshina \& Murtazin, 2012), Fundamentals of Judaic Culture (FJC) (Chlenov, Mindrina, \& Glotser, 2012), Fundamentals of Buddhist Culture (FBC) (Chimitdorzhiev, 2012), Fundamentals of World Religious Cultures (FWRC) (Beglov, Saplina, Tokareva, \& Yarlykapov, 2012), and Fundamentals of Secular Ethics (FSE) (no author, 2012). These textbooks have been written by individuals who held positions in both secular and religious institutions (Basil, 2013, p. 733), have been approved by the Ministry of Education Coordinating Council, and were published by the largest state-controlled publishing house (Prosveshchenie) in 2012. Authored by Daniliuk and identical in all textbooks, the first and last lessons articulate the course's general goals and patriotic ideals in language understandable to fourth-graders. Later in this article, I present findings from critical discourse analysis of five of these textbooks (the ones dealing with specific religious cultures). The findings reveal the latent ideological content of the textbooks, and shed light on the new course's 'hidden curriculum', to use a term from sociology of education. However, let us first look at the new curriculum's manifestly proclaimed goals and principles as they were articulated by its promoters and advocates. 


\section{Legitimizing the New Curriculum}

As mentioned above, the introduction of the new policy involved serious political struggles. Resistance and criticism came mainly in two forms. First, there was vociferous and energetic resistance from secular intellectuals, educators, opposition politicians, and human rights activists. The second type of serious resistance came from Muslim leaders (see Lisovskaya \& Karpov, 2010) and other minority religious groups who feared the new arrangements would further disadvantage them by privileging Orthodoxy. Remarkably, since the criticisms came from very different angles, both sides' arguments against bringing religion into schools emphasized the constitutionally secular nature of the Russian state and Russian education, as well as the need to protect religious freedom and human rights. These arguments resonated with the values of Western liberal democracies; it is therefore no accident that official advocates of the new curriculum chose to focus on precisely these Western values.

Telling is the following statement by the ROC MP's then official spokesman, archpriest Vsevolod Chaplinformer chairman of the Synodal Department for the Cooperation of Church and Society and a member of the Civic Chamber of the Russian Federation:

"Proposed by the President, [Dmitry Medvedev at the time-E.L.] the model of teaching religious cultures is based on the principle of free choice and has long been established in most countries of Europe and the world and everywhere contributes not only to the moral upbringing of people, but also to the strengthening of inter-religious and inter-ethnic harmony and cooperation." (Chaplin, 2009)

The emphasis here is clearly on free choice, religious liberty, and inter-religious harmony, which, along with the explicit reference to the European and global experience, implies that Russia would join the club of civilized Western liberal democracies by introducing the new religious education policy. Chaplin further stated that the new approach "satisfies interests of practically all religious groups and the groups with different world views that are actually [emphasis added-E.L.] represented in our society" (Chaplin, 2009). Let us note that the 'actually' represented groups do not include Protestants, Catholics, and many other established and new religious groups who are present in Russia and excluded from the new arrangement. The exclusionary and discriminatory aspect of this policy has been persistently glossed over by its advocates.

The same line of argument was presented by another ROC leader, Hilarion Alfeyev, the Metropolitan of Volokolamsk and Chairman of the Department of External Church Relations of the ROC:
"In Europe, and particularly in Germany, teaching spiritual and moral subjects is a common practice, in spite of the heated debates surrounding it. It is gratifying that in our country religious education in coming back to the school system after a long break." (Alfeyev, 2010)

Proponents of the new course also included in their rhetoric appeals to Russia's Law on Education, which was originally formulated in the early, relatively liberal climate of the post-Soviet transition. In particular, the Law states that,

"the content of education must contribute to mutual understanding and cooperation among people and nations irrespective of their racial, national, ethnic, religious and social affiliation; it has to accommodate the diversity of world outlooks and help students to exercise their right to the free choice of opinions and convictions." (Law on Education, 14 [4])

Following this logic, the Conception for the SpiritualMoral Development of Russia's Citizens-the foundational document behind the new course (Daniliuk, Kondakov, \& Tishkov, 2009)-promises that religious education will help future citizens of the Russian Federation internalize "the values of tolerance created on the grounds of inter-confessional dialogue" (p. 18).

Under such an interpretation, the new curriculum perfectly matches the values and expectations for religious education in Western democracies, which I discussed earlier. And-compared to the not so distant Soviet past, where religions were almost entirely suppressed, and even against earlier plans to introduce only Orthodox education in multi-religious Russia-the new policy does appear an important advancement towards religious liberty and multiculturalism. Not surprisingly, as we will see below, experts in Russia and the West have noted and emphasized these remarkable developments.

\section{Expert Evaluations}

Writing before the introduction of the new curriculum, Kozyrev and Fedorov (2007) raised the following theoretical possibilities of Russia's development in the area of religious education. Since contemporary Russian culture is rooted, they said, in "a common European cultural and religious heritage,...one might expect that the new global challenges facing Russia today will bring to life the same social, cultural and scientific developments as in the West and that that would result in growing partnerships and mutual understandings with European states" (p. 133). Yet their assessment of the place of religious education in Russia was inconclusive. On the one hand, they suggested that an increased role 
for religious education in Russia might contribute to inter-religious dialogue. However, on the other hand, and given the history of post-totalitarianism in Russia, the introduction of religious education could become "a factor of conflict" (p. 155). Against the background of this cautious assessment, later Russian evaluations of recent developments in religious education have been far more positive. For example, Romanova (2013) says that the course fits the "fundamental principle" of building "unity in diversity," which "reflects the social, ethnic, cultural, and religious complexity of Russia and the modern world" (p. 293). Overall, since the introduction of the course, criticisms by Russian experts have become less noticeable, which can be attributed-at least in part-to growing compliance with a new, far more authoritarian, ideological mainstream.

Development and implementation of the new policy did not escape the attention of Western observers (see Basil, 2013; Clay, 2015; Glanzer, 2005; Glanzer \& Petrenko, 2007; Loya, 2006, 2008; Willems, 2007, 2012). The course's multi-module, multi-religious, and multicultural structure, and its elective nature have been generally appreciated by observers, and interpreted within the discourse of accommodation for religious diversity and religious freedom. Thus, before the course was introduced in its present six-module structure, Willems (2007) argued that "schools must ensure that the other large or traditional religions can be offered similar instructions" to properly address the issue of religious freedom (p. 241). After its introduction, the six-module course structure was described as "the correct formula", signifying that many Russian leaders had the "capacity to compromise on this very difficult issue," as well as openness "to the idea of turning away from a tradition of ideological or ecclesiastical dominance, prevalent during the Romanov and Soviet eras," and a readiness "to follow a path where cooperation and negotiation replace the demands of one omnipotent opinion" (Basil, 2015, p. 739). Clay (2015) also notes the new curriculum's multicultural nature. Yet he suggests that the new Russian model of religious education "strikingly resembles the state-sponsored hierarchy of religions in the nineteenth-century Russian Empire. Increasingly, the Russian state actively cooperates with certain favored religious organizations, labelled "traditional," to achieve its social and political goals" (Clay, 2015, p. 44). This observation adds an important dimension to existing evaluations of the Russian model as convergent or inconsistent with the above described consensus on the place of religious education in liberal democracies. The Russian experience can and should be compared with Western models, yet its nature becomes clearer when we observe it in the context of Russia's own history, going back well beyond the relatively short post-Soviet and even Soviet past. Below, I take this point a step further, and suggest that Russia's emerging model can be described as neo-imperial-not only in its reliance on selected 'traditional' organizations, but also in its recreation of an imperial mode towards handling ethno-religious pluralism. This, we will see, is reflected not only in the course structure, but also in its ideological content. Thus, let us look at Russia's new model of religious education in the context of the country's imperial history and its neo-imperial aspirations.

\section{Russia's Imperial Legacies and Aspirations}

Among the many factors that have shaped Russia's approach to religious education, a most important and perhaps most overlooked one is the country's imperial legacies and the neo-imperial aspirations of its current leadership, political and religious. Historically, what we now know as the Russian Federation was once the core of two empires, Russian and Soviet. Moreover, its ethno-territorial composition and current "vertical" structure of governance is a remnant of these empires. And in the last twenty years (and increasingly in the last few years), Russia's ruling regime has worked to rebuild and regain its partly lost imperial might.

There have been debates as to how one should define empire. Yale H. Ferguson (2008) lists four main approaches for how one might identify an empire, all useful in some way. One approach simply compares the questionable empire to indisputable ones. Thus, a political entity can be considered an empire if it is similar to the Roman, Ottoman, or Tsarist Russian empires. To use Giorgio Agamben's (2009) term, the known singular cases serve as "paradigms" that help to recognize and understand unique cases while avoiding generalizations. The second approach delves more into what constitutes the essence of empirically existing empires, and attempts to give a general, "ideal type" definition. The third, "constructivist" approach relies on opinion and perception. To simplify, it holds that an entity is an empire if it is broadly perceived as one. Finally, the fourth, "normative" approach treats a polity as an empire in order to praise it or resist and change it (Ferguson, 2008, pp. 272-273). One could argue that Russia is an empire under all four criteria, but-for the purpose of this paper-let me limit the discussion to the first two. First, pre-Soviet Russia is among the aforesaid paradigmatic examples, and its Soviet version is commonly seen by social scientists as a modified reincarnation of the Tsarist original. In its present form, Russia is the largest remnant of both, and its ethno-territorial structure and even ethno-religious composition are part of its imperial legacy of conquest and colonization. Furthermore, the Russian Federation largely fits idealtypical definitions, such as Motyl's (1999) structural definition:

“Empires...are structurally centralized political systems within which core states and elites dominate 
peripheral societies, serve as intermediaries for their significant interactions, and channel resource flows from the periphery to the core and back to the periphery." (Motyl, 1999, p. 126)

When the Soviet Union was near its death, and shortly after its demise in 1991, Russian leaders appealed to regional authorities to take, in the famous words of then president Yeltsin, "as much sovereignty as you can swallow." This was instrumental in undermining the centralized structure of Soviet control, and for a short while, centrifugal tendencies were tolerated by the relatively weak central government of post-Soviet Russia. Yet a rude awakening followed when Moscow's bloody war in Chechnya set very clear limits on any aspirations for regional and ethno-territorial sovereignty. With Putin's rise to power, structural, imperial-style centralization accelerated. Since 2004, regional governors have been appointed by Moscow, and the practice of rebuilding a "vertical of power" has continued and intensified. Political discourse glorifying Russia's imperial legacy, including its Soviet hypostasis has become mainstream. Even so-called "liberals" and market reformers like Anatoly Chubais have proclaimed the creation of a "liberal empire" (Chubais, 2003). In recent years, military interventions in Georgia and Ukraine and the annexation of Crimea made Russia's neoimperial aspirations even clearer. Russia has reverted to imperial models after a short-lived attempt to change to de-centralized, democratic modes of governance and center-periphery relations. Its political structure and current prevailing orientations can thus be legitimately called neo-imperial, and it is in this context that we will look at the re-emergence of the old, albeit modified, imperial practices of handling ethnoreligious pluralism in education.

\section{Patterns of Dealing with Religious Diversity in Imperial and Neo-Imperial Russia}

A closer look at how religious and ethno-religious diversity was handled in the Russian and Soviet empires will give us better insight into the nature of the new model of religious education in contemporary Russia.

\subsection{The Russian Empire before 1917}

In the Russian Empire, ethnic and religious identities were closely interrelated. Russians were Orthodox; Chechens, Tatars, and Kazakhs were Muslims; Buryats and Kalmyks were Buddhists; and so on (e.g., Willems, 2007 , p. 232). Religious identity was practically assigned at birth, and was considered a valid indicator of one's ethnicity. Furthermore, these faiths and identities represented a hierarchical system with the ROC at the top. "The Russian legal code, systematized in the mid-nineteenth century, established a hierarchy of a handful of recognized religions" (Clay, 2015, pp. 47-48). In this hierarchy, the next, lower level was taken by other Christian confessions (inoslavie), such as the Apostolic Church, the Evangelical Lutheran Church, and the Roman Catholic Church. Judaism, Islam, and Buddhism (inoverie) were positioned at an even lower level, with different kinds of pagans occupying the bottom level (p. 48). Furthermore, and very importantly for this article's argument, the Russian Empire had what sociologists of religion would call a monopolistic division of religious markets prior to 1917 . Religious adherents belonged to historically distinct and-typicallygeographically separated ethnic groups. This meant that ethnic and religious identities were closely linked, not only to one another, but also to a particular and clearly demarcated territory. To put it differently, ethnic divisions in the country coincided with religious and territorial divisions. Thus the Russian Orthodox ethnoreligious majority group occupied the central part of the empire while minority ethno-religious groups lived on its periphery. Minority groups belonged to particular territories because they were colonized by the empire at different times in its consolidation. Thus Muslims dwelled either in Central Asia, North Caucasus, Crimea, or the Volga river Basin (Bulgaria); Buddhists lived in traditional regions south of the Ural mountains (Kalmykia) or in the Baikal region (Buryatia and Tuva); Lutherans lived to the north and west from the imperial capitals (Finland and Estonia). The fact that the first synagogue, first mosque, and first Buddhist temple were all opened in St. Petersburg-the capital of Russian Empire-only at the turn of the twentieth century (in 1888, 1913, and 1915 respectively) suggests that minority ethno-religious groups were not welcomed and did not settle in the Orthodox parts of the empire. Within this ethno-religious-territorial structure, minority religions were tolerated in that they were allowed to be practiced and even taught in schools, though within clearly demarcated geographical boundaries. Thus, Tatar children received Islamic instruction in Kazan and Crimea, Finns received instruction in Lutheranism in Finland, and Russian children were instructed in Orthodoxy everywhere they resided.

This system was a particular, imperial "regime of toleration," to borrow Michael Walzer's term (1997, p. 14). In multinational empires like Persia or Rome, Walzer explains, various cultural and religious groups could entertain a certain level of legal autonomy, ruling themselves "across a considerable range of their activities" (1997, p. 14). They co-existed with one another because they had no other choice, and because their "interactions [were] governed by imperial bureaucrats in accordance with an imperial code...designed to maintain some minimal fairness, as fairness is understood in the imperial center" (1997, p. 14). He considers this regime of imperial toleration the most historically successful at dealing with the problem of religious 
diversity (p. 15). When taxes were paid and groups did not openly object to the central authority, peaceful coexistence among groups could be maintained. However, Walzer argues that-in comparison with a liberal democracy - this type of regime is nothing more than autocratic and discriminatory, and can become "brutally repressive" (p. 15). Moreover, as shown by Barkey (2014) in her comparative study of the Habsburg and Ottoman Empires, a positive relationship between an empire and toleration of diversity should not be assumed. Toleration of diversity is not essential to imperial states (or regimes); diverse groups are incorporated for economic and/or political expediency, and states would not hesitate to engage in "serious persecution of minority populations" should there be a change in pragmatic orientation (p. 227).

It is difficult to doubt that the Russian Empire represents an imperial mode towards the toleration of diversity. Historians like Geraci and Khodarkovsky (2001) clearly show the applicability of Walzer's concept to Tsarist Russia, even though they do not use Walzer's term. In Tsarist Russia, taxes were paid and religious minorities functioned within prescribed territorial boundaries and within a centrally defined legal code; minority religions were taught in regional schools and indigenous languages under the supervision of local religious communities and organizations. Yet-grounded in the imperial model of separating ethno-religious groups into territorial enclaves on the outskirts of the country, and of relegating them a silent minority status under the bureaucratic control of the central authority-this regime represented a distinctly autocratic approach to handling cultural and religious diversity and enforcing peaceful co-existence.

\subsection{The Soviet Empire}

After 1917, schools became thoroughly atheistic. No religion was taught as a subject in its own right, and religion could not be incorporated within other subjects like history or literature, at least through the 1960s. In the 1980s, and closer to the collapse, some minimal knowledge of religions was given to students through courses on world and Russian history (Lukhovitskiy, 2005 , p. 147). Although it was difficult to completely exclude references to religions when teaching the humanities, any positive references to religious life or thought were ridiculed, banned, or excluded from legitimate educational discourse. In this sense, the Soviet model was even more secularized than the laical approach developed in France, which-according to Willaime (2007) - is not alien to incorporating religious themes within the humanities and social studies ( $p$. 64). As such, the Soviet school represents a truly extreme case of opposition to confessional or denominational teaching.

Being totally a-religious and anti-religious, the Sovi- et schools did not have to address the issue of religious diversity; religious diversity was no longer an issue. Religious life was suppressed all over the country, and existing cultural diversity no longer had a manifestly religious dimension. Thus the Soviet imperial regime did not have to exhibit toleration of religious diversity. Although religions were still practiced around the country, the state effectively and overtly exhibited intolerance towards religion. True, the intolerance was applied selectively: some churches (such as the ROC MP) were less suppressed than others (such as the Baptists or Greco-Catholics), and the selectivity resembled-to a degree-the pre-1917 hierarchical structure.

However, cultural diversity was effectively reduced to ethnic differences. Even within that realm, diversity was supposed to be limited; cultures could be national in their form, but official doctrine stipulated that cultures be socialist in their content. Soviet approaches to handling diversity evolved over time, yet they invariably aimed at suppressing ethno-national selfdetermination. This suppression included massive and forced russification of ethnic republics and regions, as well as forced relocation of ethnic groups, which changed the ethno-territorial composition of the country considerably; the country's composition became more complex and mixed than it was before the revolution. In addition to deportations and other forced relocations, the Soviet industrialization and urbanization increased geographic mobility, leading to greater ethnic heterogeneity in large cities. However, these changes did not eliminate the challenge of ethnoreligious diversity, which continued to exist, albeit in a suppressed way. Russification of the republics potentially involved their Orthodoxization, further reinforcing the minority status of non-Orthodox ethnic groups. Moreover, this mixing of cultures and ethnicities within regions prepared the ground for future tensions and conflicts, including ones that surrounded religious education in public schools after the collapse of communism (Lisovskaya \& Karpov, 2010).

\subsection{Postcommunist Russia}

As the Soviet order and its official atheism collapsed, the return of religion to the public sphere raised with renewed vigor the question of religious diversity. Russia's handling of religious diversity has reflected the prevalent pattern of its desecularization. Sociologists use the term "desecularization" (Berger, 1999) to denote the process by which religion reasserts its societal influence after a period of secularization. The process is not self-propelled. Actors and activists initiate and promote it in the direction that best serves their interests and visions. Depending on the actors involved, desecularization of public institutions may develop "from above" and "from below" (Karpov, 2010, 2013). In Russia, the predominant pattern of the return of re- 
ligion to the public sphere, including in education, was "from above." In other words, it was carried out through an alliance of religious and political elites with minimal and rigidly controlled grassroots participation (Lisovskaya \& Karpov, 2005, 2010). In the aftermath of the Soviet collapse, religious elites-especially those of the ROC MP-faced a formidable challenge. They needed to reassert their dominant role in society, but-after seven decades of atheistic suppressiontheir actual flock was negligibly small, a fact which undermined the legitimacy of any claims they might make to religious domination. Under these circumstances, the ROC MP leadership and other leading religious groups chose the path of least resistance and most efficacy. Specifically, they attempted to "reclaim" their positions of domination by re-attaching religion to ethnicity (Karpov, 2013, p.16). This meant that the ROC MP claimed all ethnic Russians as part of its flock regardless of whether 'the flock' had been baptized, attended church services, or believed in Orthodox teaching. Similarly, Russia's Muslim leadership could claim Chechens, Ingushs, Tatars, Bashkirs, and other historically Islamic people as Muslims, regardless of these peoples' religiosity or lack thereof. Buddhism was relegated to Kalmyks, Buryats, and Tuvins; Judaism was relegated to Jews, and so on. This, again, was the shortest path to reasserting the dominant societal position of these religious groups. For minority religions, i.e., non-Orthodox ones, this path was the only way to re-establish recognition, status, and control vis-à-vis the ROC MP, which claimed dominance within the hierarchy of post-Soviet religions. The path also allowed control of any competition on the religious market, and helped keep any outsiders out. In other words, this was a way to prevent and suppress any "exogenous and endogenous religious pluralism" (p. 11). The exogenous threat was-in particular-associated with American and other Protestant missionaries, who enthusiastically turned their steps to evangelize Russia in the mid1980 s, and were initially received there with great fervor. Endogenous pluralism developed from within as deviations from the official versions of Orthodoxy, Islam, and other faiths (Burdo \& Filatov, 2004; Mitrokhin, 2004; Papkova, 2011). For example, mass conversions to Pentecostalism in Siberia and the Far East (territories perceived as canonically Orthodox) represented both an exogenous and endogenous threat to the ROC MP domination. The high rate of conversions, in particular, led to changes in legislation on religion (Shterin, 2012). Trying to minimize the challenge of pluralism, the ROC MP leadership lobbied for "The Freedom of Conscience and Religious Associations", which was passed in 1997 and privileged Orthodoxy, Islam, Buddhism, and Judaism as Russia's traditional faiths. All other religions were deemed 'non-traditional', and their rights were curtailed. Especially disadvantaged were the newly arriving or re-emerging groups affiliat- ed with Protestant and other Western religions, such as the Salvation Army, Jehovah's Witnesses, Mormons, and many others. The definition of 'traditional' religions or religious organizations is missing from the law. However, it may be found in the Manual for teachers of religious cultures (Tishkov \& Shaposhnikova, 2011). Traditional religions are there defined as those that have been "transmitted from one generation to another within a particular entity of people. They develop within ethnic or state-defined boundaries" (p. 203). This definition clearly resonates with the ethnoterritorial religious divisions of the Russia Empire. The 2015 edition of the 1997 law reinforces this resemblance by stipulating that a religious organization may be established by "the citizens permanently living on the same territory or in one settlement of urban or rural type" (Amendments to the 1997 Law, 2015). The logical outcome of this strategy was a reestablishment (albeit a modified one) of the imperial model for dealing with religious diversity. The boundaries of religious communities have once again become co-extensive with ethnic and territorial boundaries. Making this neoimperial model legitimate in people's eyes represented a serious challenge for elites, although it was deeply rooted in pre-revolutionary patterns and mentality. First, the successful imposition of such a model had to overcome social-structural and psychological obstacles. In particular, during Soviet ethnic mixing and migration, the boundaries between ethno-religious communities substantially disintegrated and lost their distinctive character. Second, in spite of decades of atheism, religious conversions did not come to a total halt, which corroded the once solid connections between a particular religion and its corresponding ethnicity. Thus Orthodox Christians became Baptists, Muslims converted to Lutheranism, and some even joined the International Society of Krishna (Willems, 2007, p. 232). Finally, boundaries between religious communities were more often imagined than real because levels of religious belief, belonging, and behavior were quite low after years of atheism.

To revive, inculcate, and disseminate the beliefs that ethnic and religious boundaries are essentially intertwined, and that crossing these boundaries should be viewed with suspicion and be discouraged, a particular type of ideology was propagated. In my previous, co-authored work, the ideology is dubbed "ethnodoxy", and conceptualized as a "belief system that rigidly links a group's ethnic identity to its dominant religion and consequently tends to view other religions as potentially or actually harmful to the group's unity and wellbeing and, therefore, seeks protected and privileged status for the groups' dominant faith" (Karpov \& Lisovskaya, 2008, p. 370; Karpov, Lisovskaya, \& Barry, 2012, p. 644).

It is in this context of limited pluralism-reverting to a neo-imperial regime of inter-faith relations, ethni- 
cization, territorial binding of religion, and propaganda of ethnodoxy - that the new Russian model of religious education is best understood. The structure and content of the new curriculum are functional within the neo-imperial model. First, it selectively privileges some religions and effectively excludes others. Second, it retains the privileged status of Orthodoxy vis-à-vis other religions. Third, it promotes ethnodoxy by involuntarily including students in and excluding them from preassigned ethno-religious categories. Findings from my discourse analysis of the five modular textbooks and the teachers' Manual show how these unarticulated goals are meant to be achieved. The analysis leads me to conclude that the ideas of the course are congruent with the neo-imperial ideology of the Russian state. Let us now turn to the analysis and its findings.

\section{Findings from Discourse Analysis}

\subsection{Suppression of Exogenous Religious Pluralism}

The course obviously limits the range of studied religions to Orthodoxy, Islam, Buddhism, and Judaism. This range of inclusion and exclusion mirrors the restrictive 1997 law. The 'big four' are taught in separate modules, and to each is devoted a specially developed textbook. No modules exist for non-Orthodox Christians. For the millions of Russian Protestants, no module exists on the Fundamentals of Protestant Culture. No module exists for perhaps a million Russian Catholics, nor for the 1.5 million Armenian Apostolic Christians (numbers taken from Clay, 2015, p. 56). One of the course's five modules covers the textbook, Fundamentals of World Religious Cultures (FWRC). Here, one would expect to find other religions discussed. However, this isn't entirely the case. The FWRC textbook (Beglov et al., 2012) primarily focuses on the four traditional faiths; it mentions paganism in passing, and gives scant attention to Roman Catholicism, Western Protestantism, and the Armenian Apostolic church. Presentation of these religions spans 1.3 pages out of the FWRC textbook's 79 pages. Information about these nonOrthodox branches of Christianity is scarce. Protestantism is represented as one undifferentiated religion. Information is often inaccurate and biased. Thus students learn that the Orthodox Church was established after the Great Schism between Eastern and Western Christianity in the eleventh century. 'Orthodox' is translated as, "teaching about God correctly and truthfully" (pp. 46-47). The limited space of this article precludes a detailed analysis of these interpretations, yet it is clear that the textbook's interpretations are historically and semantically inaccurate and and biased in favor of Orthodoxy. For example, the term 'Orthodoxy' hardly means 'correct church', and such a translation has an unfavorable connotation for other Christian churches.
The course's Teachers' Manual (Tishkov \& Shaposhnikova, 2011) reinforces these attitudes towards non-Orthodox churches. Interestingly, the Manual's discussion of Roman Catholicism is lengthy and detailed, consuming 13 pages, which is comparable to its presentations of Judaism (17 pages) and Islam (22 pages). However, it presents Catholicism as entirely foreign to Russia. The chapter on Catholicism gives no mention of Catholicism or Catholics in Russia (pp. 102-116). The presentation of Protestantism spans 25 pages, and selectively identifies only four Protestant denominations-Lutherans, Seventh Day Adventists, Pentecostals, and Baptists (pp. 117-141); certainly, these four denominations do not exhaust all Protestant groups in contemporary Russia. Given that Protestants constitute the third largest group of believers in modern Russia (Kozyrev \& Fedorov, 2007, p. 135), 25 pages isn't exactly excessive next to the 24 pages devoted to Orthodoxy. Like the Roman Catholic Church, the Lutheran Church is portrayed as foreign to Russia, even though it is Russia's oldest and most influential Protestant denomination. Only ten lines at the end of the chapter are devoted to Lutheranism; these lines mention that the Lutheran Church was established in 1576, and was primarily attended by people of Finnish and German origins (Tishkov \& Shaposhnikova, 2011, p. 125), once again implying the ethnic boundaries of religious affiliation. At the same time, the Manual doesn't indicate the rapidly growing numbers of Protestants in Russia; charismatic and Pentecostal Christians in Siberia and the Far East (Kozyrev \& Fedorov, 2007, p. 135) largely reflect the conversions of ethnic Russians. Since these facts disagree with the dominant ethnodoxy, they are ignored.

The notion that 'non-traditional' faiths are fundamentally problematic is reinforced by the definition the Manual provides of 'new' religions. First, the Manual explains that 'new' religions are synonymous with 'non-traditional' ones, and that they may include both emerging (recent) and re-emerging (historically old) religions (Tishkov \& Shaposhnikova, 2011, p. 202). Although this is not explicitly articulated in the Manual, such an understanding allows for categorizing Catholicism and Protestantism as 'new' religions since they are re-emerging religions. Secondly, and more importantly, the 'new' religions are described-in sharp contrast with 'traditional' ones-as less concerned with faith as such, and more concerned with earthly matters. They are said to be rooted in the emotional and psychological aspects of faith rather than its doctrinal dimensions, and as appealing to young people's desires to belong to a collectivity of like-minded people, as well as to their immature susceptibility to peer pressure (pp. 204-207). Making 'non-traditional' (or 'new') religions even less attractive, the Manual cites the document accepted at the Hierarchical Council of the ROC in 1994, which declares all 'new' religions "incompatible with Christianity" (p. 210). 


\subsection{Suppression of Endogenous Pluralism}

Suppression of endogenous pluralism is similarly achieved through inclusion of the 'right' and exclusion of the 'wrong' factions and currents within confessions. We have already seen that Christianity is discussed in a very limited way in the World Religions textbook and in the Manual. All other textbooks give little if any attention to religious diversity within faiths. Thus, the textbook on Orthodox Culture heavily focuses on a generic type of Russian Orthodoxy. Not a single Orthodox group outside of the ROC MP is mentioned. Students will learn nothing about the Old Believers and Russian Orthodox Church Outside of Russia (formerly in Exile), let alone the Ukrainian Autocephalous Orthodox Church, or the Orthodox Church of Kyiv Patriarchate that broke from the ROC.

Similarly, while the textbook on Islam (Latyshina \& Murtazin, 2012) rightly calls Islam a "world religion" and mentions that there are 1.5 billion Muslims on the planet (p. 6), it bypasses the enormous diversity within Islam. It neither discusses nor mentions the Shia-Sunni split, Sufism, Ahmadiyya, or other currents. The Teacher's Manual is equally silent on the issue of Islamic diversity.

In a remarkable contrast, textbooks on Buddhist (Chimitdorzhiev, 2012) and Judaic Cultures (Chlenov et al., 2012) acknowledge internal religious diversity and different interpretations within the faiths. Buddhism is represented by three teachings-Theravada, Mahayana, and Gelug (or Gelukpa). None of the three-including Gelug, the most common strand in Russia-is described as more truthful or better than the others (Chimitdorzhiev, 2012, p. 32). Similarly, the Judaic Culture textbook discusses Orthodox, Conservative, and Reformed Judaism, as well as Hassidism. Although its interpretation of Reformed Judaism as "simplifying" and "distancing from Orthodox Judaism" (Chlenov et al., 2012, p. 56) possesses a disapproving connotation, this textbook is the only one of the five that gives a definition of religious tolerance (veroterpimost') as "acceptance of the right of other faiths to exist freely" (p. 7).

\subsection{Ethnodoxy}

All textbooks on religious cultures mention the historical connections between nationalities (ethnicities) and particular religions. However, not all represent this connection as rigid and inseparable. Ethnodoxy is particularly strong in the textbooks on Orthodox and Islamic cultures. The first textbook on Orthodox culture by Borodina (2002) presented Orthodoxy as inseparable from Russianness and Slavic ancestry (Shnirelman, 2012, p. 264). The 2012 Orthodox Culture textbook strengthens this connection. Students are taught that a person "does not typically choose his/her culture. They are born into it, breathe it, and grow within it" (Kuraev, 2012 , p. 6). The textbook instructs that, to properly understand "all that is connected to the world of religion," students should look inside their souls and to "feel its connection to Motherland [i.e., to RussiaE.L.]" (p. 32). Although the textbook is supposed to be about Orthodox culture in general, it represents Orthodoxy as an essentially Russian phenomenon. It provides no distinction between the Orthodox Church proper and the Russian Orthodox Church as a particular embodiment of Orthodoxy. In this sense, the textbook is on Russian Orthodoxy, not on Orthodox culture. For example, it admits that in "Orthodox Church prayer and sermon may be in languages other than Russian." However, immediately after this concession, it suggests that the "Russian [emphasis mine] Orthodox Church prays in Japanese, English, German and many other languages" (p. 54). By doing so, the textbook subtly implies that all Orthodox churches-regardless of the language in which they conduct services-fall under the jurisdiction of the ROC MP. Why a service conducted in English does not belong to the American Orthodox Church, or why Greek services do not belong to the Greek Orthodox Church is left unexplained. In the fine print, it admits that other Orthodox Christians exist in "Bulgaria, Serbia, and Czech Republic" (p. 54). Yet the range of "other countries" is limited to these three Slavic nations, leaving aside the rest of the world, where Orthodoxy was introduced much earlier or took root later. Especially salient, the overtly Russian nature of what is presented as Orthodoxy manifests itself in how the textbook describes Easter. Although Easter is a common feast for all Christians, the textbook uses the concept 'Russian Easter' interchangeably with the concept 'Christian Easter,' thus implying that specifically Russian traditions for celebrating Easter are the same traditions celebrated by the whole of Christendom (pp. 29-31).

The link between Orthodoxy and Russianness is further emphasized in the story of the tenth century baptism of the people of Kyivan Rus', which is recounted in both the Orthodox and World Religious Cultures textbooks. This adaptation is done entirely in the spirit of cultural-imperialist appropriation; the Kyivan Rus' is appropriated as Kyivan Russia, even though the former is also the cradle of the Ukrainian and Belarusian cultures and nations, and even though Ukrainian GrecoCatholics legitimately trace their roots to the times of acceptance of Orthodoxy by ancient Rus'. Such an imperialist appropriation of Rus' is by no means novel. Appropriation is part of the Russian religious nationalism that has been cultivated since the second half of the nineteenth century, and resurged in Russia after the collapse of communism. This ideology is clearly present in both the Orthodox and World Religious Culture textbooks. Both textbooks (Kuraev, 2012, and Beglov et al., 2012) blur the distinction between Russians and the people of the Rus'. The texts consistently refer to the people of Kyivan Rus'-its princes Vladimir 
and Jaroslav, and their ambassadors to Constantinople-as 'Russians' (russkie) (Beglov et al., 2012, p. 42; Kuraev, 2012, p. 59). Further, the textbooks represent the adoption of "Orthodoxy" (which, strictly speaking, did not exist as a confession at the time of baptism of Rus' in 988 A.D.) as the starting point for the establishment of 'Holy Russia,' a mythologeme that has occupied a central role in Russian religious nationalism and imperialism from the Tsarist times to the annexation of Crimea in 2014. Let us note that-in this regard-the textbooks' ideas have become congruent with the neo-imperialist ideology that has been cultivated in Russia and used to justify its openly expansionist aspirations. The Orthodox Culture textbook explains the meaning of 'Holy Russia' as the Russian people's "search for holiness" (Kuraev, 2012, p. 60). It notes that "high appeals of the Gospel found a quick response among Russian people after they had been baptized" (p. 59). This all sounds as if the people of Rus' (read 'Russians') were predestined to become Orthodox believers, and that no other faith could possibly match "the Russian soul" or Russian worldview. From these presentations, students are likely to learn that being ethnically Russian means being Orthodox-as if by birth-and that being Orthodox ultimately means being Russian.

Finally, this belief is enhanced by the overall aesthetics of the Orthodox Culture textbook. All illustrations and photographs represent Russian churches, Russian icons, Russian art, or stereotypically Russian individuals. There are fifteen photographs of lay people in the textbook in which the photographed persons' facial features are clearly recognizable. All are stereotypically Russian (or at least Slavic), with blond hair, beards or braids, and blue eyes. No Asian-looking (e.g., Tatar or Yakut) physiques or features can be found among the pictures. Moreover, to reinforce attribution of Orthodoxy to the Russian land, the textbook liberally uses appropriate imagery-both visual and verbal-of typical Russian nature and landscapes. For example, a lengthy excerpt from Solzhenitsyn narrates that the "Orthodox churches and bell towers are the key for understanding the conciliatory nature of Russian landscape..... In these very bell towers our ancestors had invested the best of them, all their understanding of the meaning of life" (Kuraev, 2012, p. 61).

The Islamic Culture textbook is no less permeated with ethnodoxy. Throughout the text, the word 'Muslim' and ethnic markers are used interchangeably. For example, in the lesson on customs and morals, it is noted that "Muslims are very hospitable. If you happen to be a guest in the house of a mountaineer, such as an Ingush, Chechen, or Avar", you will be given everything you need (Latyshina \& Murtazin, 2012, p. 67). Similarly, heroic acts of "Muslim people" in times of war or peace are discussed as the "heroism of Bashkir or Dagestani people" (p. 55). Three examples of "Muslim he- roes" are remarkable in this sense. One is Musa Dzhalil', a Soviet poet who died in a Nazi camp. Another is Abdul Khakim Ismailov, a soldier, one of those who erected the Soviet banner over Reichstag in May of 1945. The third is Makhmud Esambaev, a famous dancer in the Soviet Union. Who were these people? Dzhalil' and Ismailov were members of the Communist Party of the USSR. All three were recipients of numerous Soviet-time governmental awards, and experienced the peak of their popularity under Soviet atheism. However, the textbook unequivocally labels them 'Muslims.' This labelling is done posthumously, and thus ascribes religious identity arbitrarily (pp. 54-57). What, then, makes them Muslim? The answer is clear. The only aspect that makes these heroes Muslim is their membership in traditionally Islamic ethnicitiesone was a Tatar, another Dagestani, and the last Chechen. Thus, the students are subtly but surely forced to develop a rigid connection between ethnic and religious identity.

Of the five textbooks, the ones on Judaic and Buddhist cultures show the least evidence of ethnodoxy. Moreover, they include a number of anti-ethnodox statements. Both FJC and FBC emphasize the global reach of Judaism and Buddhism, and do not necessarily relate these religions to particular ethnicities or geographic territories. Statements like these typify the textbooks' content:

"millions of people in various countries glorify Buddha." (Chimitdorzhiev, 2012, p. 8)

"Buddhist rituals emerged and developed under the influence of traditions and customs of various peoples, different in their culture, language and lifestyle." (p. 52)

Similarly, the Judaic Culture textbook shows a low or non-existent level of ethnodoxy. The text differentiates between 'religious' and 'non-religious' Jews, and suggests that one does not have to be religious to be considered an ethnic Jew (Chlenov et al., 2012, p. 7). By so saying, the text suggests that the religious marker of Jewishness is not rigidly attached to its ethnic marker. Moreover, by suggesting that members of any ethnicity who pass an exam may become a Jew in religious terms (p. 67), the textbook paints the ethno-religious boundary as permeable. However, it is permeable in only one direction. Ethnicity does not presuppose religiosity, but acceptance of Judaism automatically includes one in the "Jewish people" (p. 7). Thus, students of the Judaic culture textbook receive a mixed message on the link between ethnicity and religion. The ethnoreligious boundary seems to work as a one-way street, i.e., religion assumes ethnicity, but not the other way around. Let us note, however, that while this representation only partly fits our definition of ethnodoxy, eth- 
nodoxy itself is a foundational dogma within Judaism. It reflects an essential dogma of Judaism rather than an ideological interpretation of the faith.

\subsection{Hierarchy of Religions}

As mentioned above, the idea of the hierarchy of religions is central to the neo-imperial model of dealing with religious diversity, and is clearly reinforced by the textbooks discussed. These textbooks put the ROC at the top of the religious hierarchy. The textbooks do not say this directly. However, the notion is promoted through how they represent each religion's relation to the Russian state. Therefore, it is remarkable that each textbook glorifies the role of the state in the historical and contemporary development of the faith it discusses. Yet each faith's position in the hierarchy of religions becomes obvious through what the textbooks specifically do or do not say about the Russian state. Unsurprisingly, representations of how the ROC stands vis-àvis the state unmistakably indicate that the Church possesses a much higher status than Islam, Buddhism, or Judaism. For example, only the FWRC textbook recounts some of the historical faults of the state towards the Orthodox Church, such as Peter the Great's abolition of the institution of Patriarchate (Beglov et al., 2012, p. 46). The ROC is depicted as a victim of illtreatment by the state, on the one hand, and as an important player in the history of Russian society on the other. Thus Orthodoxy emerges as an invariably positive force, while the state is portrayed as capable of injustices (albeit only past and limited ones). Yet any historical injustices by the state towards minority religions have been totally omitted from the textbooks. Moreover, the Judaic and Buddhist culture textbooks not only gloss over all instances of mistreatment by the state, but also ignore the positive contributions of Judaism and Buddhism to the Russian state and society. When speaking of the Russian State, the textbooks express only gratitude. For example, the Buddhist culture textbook thanks Elisabeth II for officially recognizing that Buddhism existed in Russia in 1741 (Chimitdorzhiev, 2012, p. 38). The textbook emphasizes that a temple in Buryatia was built in memory of Russia's victory over Napoleon in 1812 (p. 64). The Judaic Culture textbook gratefully brings up the February Revolution of 1917, which "removed all forms of inequality of Jews as citizens and made Judaism equal with all other religions in the country" (Chlenov et al., 2012, p. 48). Not a word of criticism of the state policy against Buddhists or the state-supported anti-Semitism is uttered. Islam seems to construe its status somewhere between-on the one hand-Buddhism and Judaism and-on the other-Orthodoxy. The Islamic culture textbook neither praises the Russian State for its support, nor blames it for any ill-treatment of Islam or Muslims. Yet, similarly to the Orthodox culture text, it strongly emphasizes the contributions of Islam to Russian culture (Latyshina \& Murtazin, 2012, pp. 52-53). In sum, Orthodoxy has an invariably positive image, and was unjustly treated by the state. Islam contributed positively to Russia, but the textbook mentions no state injustices against Muslims. Finally, Judaism and Buddhism are thankful recipients of state favors, yet none of the religions' positive contributions are mentioned.

Thus, the textbooks' content demonstrates that the ROC is entitled to boast not only of its contributions to the Russian state and nation, but also to remember that it was once hurt by it. Islam is not entitled to remember any wounds, but is allowed to claim its contributions. Buddhism and Judaism may only thank the state for its favors. The hierarchy that transpires is very clear. I conclude that, by means of these representations, the studied textbooks approve the existing hierarchical relationships between religions and vis-à-vis the state. Such approval provides ideological support to the neo-imperial model of religious toleration in the context of-to use Motyl's definition of empires-"structurally centralized political system[s] within which core states and elites [including the ROC MP elites-E.L.] dominate peripheral societies" (1999, p. 126).

\section{Conclusion}

We have seen that the content of the textbooks designed for the religious education of Russian students exhibits a specific constellation of ideological characteristics. These include bypassing the reality of exogenous and-in the cases of Orthodox and Islamic textbooks-endogenous pluralism. Furthermore, the textbooks on Orthodox and Islamic cultures-whose combined target audience accounts for the vast majority of Russia's students - promote the ideology of ethnodoxy, which rigidly links religion to ethnicity and leads to negative perceptions of ethnically "alien" faiths. Moreover, the Orthodox Culture textbook employs mythologemes and interpretations that have been historically central to Russian religious nationalism and imperialism, and that are congruent with the neo-imperialist expansionism of Russia's current leadership and its dominant ideology. Finally, the textbooks perpetuate the notion of an imperial, state domination of religious minorities, as well as a hierarchy of religions in which the ROC MP sits at the top. These findings indicate the function that religious education is supposed to fulfill in contemporary Russia. The manifestly proclaimed goals of religious education appear convergent with the values of religious freedom, selfdetermination, tolerance, and inter-faith peace that are espoused by Western liberal democracies. Yet the hidden curriculum of religious education that shows in this constellation of ideological characteristics is far more consistent with a neo-imperial model of an ethno-religious hegemony (of Russian Orthodoxy) and 
with limited toleration of selected faiths whose reach is supposedly restricted to politically peripheral ethnoterritorial entities. This model embodies and revitalizes Russia's imperial legacies. Yet this revitalization is in itself an outcome of strategic choices made by the country's religious and secular elites.

As was mentioned above, the neo-imperial model emerged as a result of a lengthy process that involved intense contestation and political struggle. However, in the current, increasingly authoritarian political atmosphere, any further contestation of the neo-imperial model of ethno-religious hegemony has been shunned.

Yet no matter how much the new model resonates with Russia's imperial traditions and current authoritarianism, it may be a short-lived creation. Social and geographic mobility in today's Russia undermines ethno-territorial approaches to religious pluralism. The suppression of pro-independence movements in Russian regions requires resources of which Russia may run out in the not so distant future. The "vertical of power" that has enforced the hierarchy of religions may crumble as a result of economic and socio-political challenges. And, finally, globalization leads to a rapid growth of religious diversity, and undermines traditional, imperial approaches. Under these circumstances-and if it wishes to preserve itself as a unified political entity-Russia must adopt a much more consistently pluralistic and non-hegemonic model of religious education.

\section{Acknowledgments}

I thank Dr. Vyacheslav Karpov, whose professional insight and expertise greatly assisted in this research.

\section{Conflict of Interests}

The author declares no conflict of interests.

\section{References}

Agamben, G. (2009). The signature of all things: On method. New York, NY: Zone Books.

Alfeyev, H. (2010). Teaching religion in public school: Important discussion in Russia and in Germany. Russian Orthodox Church. The Official Website of the Department for External Church Relations. Retrieved from

http://www.mospat.ru/ru/2010/02/24/news13598

Amendments to the1997 Law "On Freedom of Conscience and Religious Organizations." (2015, July 13). Article 9 (1). [Обзор изменений Федерального закона от 26.09.1997 N 125-Ф3 «О Свободе Совести и о Религиозных Объединениях.» Редакция от 13.07. Редакция от 13.07.2015 Артикль 9, пункт 1]. Retrieved from https://www. consultant.ru/document/cons_doc_LAW_79440/912
Of33f541a09d2acd9d5e260401f5a0c84247c/\#dst100 015

Barkey, K. (2014). Empire and toleration: A comparative sociology of toleration within Empire. In A. Stepan, \& C. Taylor (Eds.), Boundaries of toleration (pp. 203232). New York, NY: Columbia University Press.

Basil, J. D. (2013). Russian school textbooks on religion: Theological learning, ideological confrontation, or religious education. Journal of Church and State, 55(4), 712-739.

Beaman, L., \& Van Arragon, L. (Eds.). (2015). Issues in religion and education (Vol. 25). Leiden, the Netherlands: Koninklijke Brill NV.

Beglov, A. L., Saplina, E. V., Tokareva, E. S., \& Yarlykapov, А. А. (2012). Основы Мировых Религиозных Культур [Fundamentals of world religious cultures]. Moscow: Prosveshchenie.

Berger, P. (1999). The desecularization of the world: Resurgent religion and world politics. Grand Rapids, $\mathrm{MI}$ : William B. Eerdmans Publishing Co.

Borodina, A. B. (2002). Osnovy pravoslavnoi kul'tury [Fundamentals of Orthodox culture]. Moscow: Pokrov.

Burdo, M., \& Filatov, S. (Eds.). (2004). Sovremennaia religioznaia zhizn' v Rossii: Opyt sistematicheskogo opisaniia [Contemporary religious life in Russia: An attempt of systematic description] (Vol. 1). Moscow: Logos.

Chaplin, V. (2009). Prisutstvie religioznoi kul'tury v shkole i dukhovenstva v armii: Eto estestvenno I normal'no dlia sovremennogo obschestva. [Presence of religious culture in school and in the army is natural and normal in contemporary world]. Sedmitsa-RU. Retrieved from http://www.sedmitza.ru/text/742809.html

Chlenov, M. A., Mindrina, G. A., \& Glotser, A. V. (2012). Osnovy iudeiskoi kul'tury [Fundamentals of Judaic culture]. Moscow: Prosveshchenie.

Chimitdorzhiev, V. L. (2012). Osnovy buddiiskoi kul'tury [Fundamentals of Buddhist culture]. Moscow: Prosveshchenie.

Chubais. A. (2003). Russia should aim to create liberal empire in CIS. Pravda.ru. Retrieved from http:// www.pravdareport.com/news/russia/25-09-2003/ 52757-0

Clay, E. (2015). Multiculturalism and religious education in the Russian Federation: The Fundamentals of Religious Cultures and Secular Ethics. State, Religion and Church, 2(1), 44-74.

Daniliuk, A. I., Kondakov, A. M., \& Tishkov, V. A. (2009). Концепция духовно-нравственного развития $и$ воспитания личности гражданина России [Conception for the spiritual-moral development and upbringing of the personality of the citizen of Russia]. Moscow: Prosveshchenie. Retrieved from http:// www.r-komitet.ru/school/program/action2009/ razdel/cdn

Ferguson, Y. H. (2008). Approaches to defining "Empire" 
and characterizing United States influence in the contemporary world. International Studies Perspectives, 9, 272-280.

Fetzer, J., \& Soper, C. (2005). Muslims and the state in Britain, France, and Germany. New York, NY: Cambridge University Press.

Fundamentals of secular ethics [Основы Светской Этики]. (2012). Moscow: Prosveshchenie.

Geraci, R., \& Khodarkovsky, M. (Eds.). (2001). Of religion and empire. Missions, conversion, and tolerance in Tsarist Russia. Ithaca, NY: Cornell University Press.

Glanzer, P. (2005). Postsoviet moral education in Russia's state schools: God, country and controversy. Religion, State and Society, 33(3), 207-221.

Glanzer, P., \& Petrenko, K. (2007). Religion and education in post-communist Russia: Russia's evolving church-state relations. Journal of Church and State, 49(1), 53-73.

Grelle, B. (2015). Neutrality in public school religion education: theory and politics (pp. 231-256). In Beaman, L. \& L. Van Arragon (Eds.), Issues in religion and education (Vol. 25). Leiden, the Netherlands: Koninklijke Brill NV.

Jackson, R. (Ed.). (2003). International perspectives on citizenship, education and religious diversity. London: RoutledgeFalmer.

Jackson, R. (2007). European institutions and the contribution of studies of religious diversity to education for democratic citizenship. In R. Jackson, S. Miedema, W. Weisse \& J-P. Willaime (Eds.), Religion and education in Europe: Developments, contexts, and debates (pp. 27-55). New York, NY: Waxmann Münster.

Jackson, R. (2010). Foreword. In K. Sporre \& J. Mannberg (Eds.), Values, religions and education in changing societies (pp. v-ix). New York, NY: Springer.

Jozsa, D-P. (2010). Islam in education: A contribution to dialogue or a factor of conflict? In K. Sporre \& J. Mannberg (Eds.), Values, religions and Education in changing societies. New York, NY: Springer.

Karpov, V. (2010). Desecularization: A conceptual framework. Journal of Church and State, 52(2), 232270.

Karpov, V. (2013). The social dynamics of Russia's desecularization. Religion, State, and Society, 41(3), 254283.

Karpov, V., \& Lisovskaya, E. (2008). Religious intolerance among Orthodox Christians and Muslims in Russia. Religion, State \& Society, 36(4), 361-377.

Karpov, V., Lisovskaya, E., \& Barry, D. (2012). Ethnodoxy: How popular ideologies fuse religious and ethnic identities. Journal for the Scientific Study of Religion, 51(4), 638-655.

Kozyrev, F., \& Fedorov, V. (2007). Religion and education in Russia: Historical roots, cultural context and recent developments. In R. Jackson, S. Miedema, W. Weisse, \& J-P. Willaime (Eds.), Religion and education in Europe: Developments, contexts, and debates (pp.
133-158). New York, NY: Waxmann Münster.

Kuraev, A. V. (2012). Osnovy pravoslavnoi kul'tury [Fundamentals of Orthodox Culture]. Moscow: Prosveshchenie.

Lahnemann, J., \& Schreiner, P. (Eds.). (2009). Interreligious and values education in Europe: Map and handbook. Münster: Comenius-Institut.

Latyshina, D. I., \& Murtazin, M. F. (2012). Osnovy islamskoi kul'tury [Fundamentals of Islamic Culture]. Moscow: Prosveshchenie.

Lisovskaya, E., \& Karpov, V. (2005). La religion dans les écoles russes: Une désécularisation contestée [Religion in Russian Schools: A contested desecularization]. In J-P. Willaime \& S. Mathieu (Eds.), Des maîtres et des Dieux: Ecoles et religions en Europe (pp. 181-192). Paris: Belin.

Lisovskaya, E., \& Karpov V. (2010). Orthodoxy, Islam, and the desecularization of Russia's state schools. Politics and Religion, 3(2), 276-302.

Loya, J. (2006). Religion classes in state institutions in post-Soviet Russia. Religion in Eastern Europe, 26(1), 52-66.

Loya, J. (2008). Religious education initiatives in Russia: Update and commentary. Religion in Eastern Europe, 28(2), 18-27.

Lukhovitskiy, V. (2005). Religioznoe obrazovanie v svetskoi shkole [Religious education in secular school]. In A. Verkhovskiy (Ed.), Predely svetskosti [Limits of secularity] (pp. 146-161). Moscow: SOVACenter.

Mitrokhin, N. (2004). Russkaia Pravoslavnaia Tserkov': Sovremennoie sostojaniie $i$ aktual'nyie problemy. [Russian Orthodox Church: Current state and the problems of actual interest]. Moscow: Novoie Literaturnoie Obozreniie.

Monsma, S., \& Soper, L. C. (1997). The challenge of pluralism. Church and state in five democracies. Lanham, MD: Rowman \& Littlefield.

Motyl, A. J. (1999). Revolutions, nations, empires: Conceptual limits and theoretical possibilities. New York, NY: Columbia University Press.

OSCE. (2007). Toledo guiding principles on teaching about religions and beliefs in public schools. Warsaw: Organisation for Security and Co-operation in Europe, Office for Democratic Institutions and Human Rights.Retrieved from http://www.osce.org/odihr/ 29154

Papkova, I. (2011). The Orthodox Church and Russian politics. New York, NY: Oxford University Press.

Plesner, I. T. (2005a). Legal limitations to freedom of religion or belief in school education. Emory International Law Review, 19, 557.

Plesner. I. T. (2005b). Freedom of religion or belief in public schools. Paper presented at "Ecole et Religions" European colloquial, Paris, IESR, 15-16 October 2004.

Richardson, J. (Ed.). (2004). Regulating religion. Case 
studies from around the globe. New York, NY: Kluwer Academic/Plenum Publishers.

Romanova, E. (2013). Religious education in modern Russia. In D. Davis \& E. Miroshnikova (Eds).), The Routledge international handbook of religious education (pp. 287-294). New York, NY: Routledge.

Shnirelman, V. (2012). Russian Orthodox culture or Russian Orthodox teaching? Reflections on the textbooks in religious education in contemporary Russia. British Journal of Religious Education, 34(3), 263-279.

Shterin, M. (2012). Conversion after socialism: Disruptions, modernisms and technologies of faith in the former Soviet Union. Religion, State and Society, 40(1), 162-165.

Stenogramma. (2012). Stenogramma vstrechi predsedatelia Pravitel'stva RF V.V. Putina so Sviateishim Patriarkhom Kirillom i liderami traditsionnykh religioznykh obschin Rossii [A stenographic record of the meeting of the president of the government of the Russian Federation V. V. Putin with His Holiness Patriarch Kirill and leaders of traditional religious communities of the Russian Federation]. Патриархия.ru [Patriarkhiia.ru]. Retrieved from www.patriarchia.ru/ db/print/2005767.html

Tishkov, V. A., \& Shaposhnikova, T. D. (Eds.). (2011). Instructional manual for teachers. Grades 4-5 (2nd ed.). Moscow: Prosveshchenie.

Van Arragon, L., \& Beaman, L., (2015). Introduction. In L. Beaman \& L. Van Arragon (Eds.), Issues in religion and education (Vol. 25, pp. 1-15). Leiden, the Netherlands: Koninklijke Brill NV.

Vasilenko, K. (2005). Ne boisia Boga: Patriarkhiia nastaivaet na religioznykh urokakh [Do not be afraid of God: Moscow Patriarchate insists on teaching religion]. Vremia Novostei [News Times]. Retrieved from http://religion-sova-center.ru/events/13B7455/273 A135?month $=2005-01$

Walzer, M. (1997). On toleration. New Haven and London: Yale University Press.

Weisse, W. (2007). The European research project on religion and education "REDCo." In R. Jackson, S. Miedema, W. Weisse, \& J-P. Willaime (Eds.), Religion and education in Europe: Developments, contexts, and debates (pp. 9-25). New York, NY: Waxmann Münster.

Willaime, J-P. (2007). Teaching religious issues in French public schools. From abstentionist laïcité to a return of religion to public education. In R. Jackson, S. Miedema, W. Weisse \& J-P. Willaime (Eds.), Religion and education in Europe: Developments, contexts, and debates (pp. 87-101). New York, NY: Waxmann Münster.

Willems, J. (2007). Fundamentals of Orthodox Culture (FOC): A new subject in Russia's schools. British Journal of Religious Education, 29(3), 229-243.

Willems, J. (2012). "Foundations of Orthodox Culture" in Russia. Confessional or nonconfessional religious education? European Education, 44(2), 23-43.

\section{About the Author}

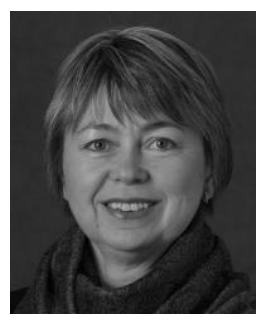

\section{Dr. Elena Lisovskaya}

Elena Lisovskaya is Professor of Sociology at Western Michigan University. Her interests are in comparative studies of ideological and institutional changes with foci on education and religion. She has published on privatization, dogmatism, and new ideologies of textbooks. Since the 2000s, she has engaged in comparative research on desecularization and religious education, and has co-authored $R e$ ligious Intolerance among Orthodox Christians and Muslims in Russia (2008); Orthodoxy, Islam, and the Desecularization of Russia's State Schools (2010); Ethnodoxy: How Popular Ideologies Fuse Religious and Ethnic Identities (2012); and others. 